\title{
Северный Донбасс в экономической и политической системе Российского государства в XVI-XVII вв.: юрты, сторожи, города на Поле
}

\author{
Г.Г. Чепига \\ Донецкая государственная музыкальная академия имени С.С. Прокофьева, \\ ДНР, 83086, г. Донецк, ул. Артема, д. 44 \\ E-mail: chepiga_galina@mail.ru
}

\begin{abstract}
Аннотация. Данная статья посвящена вопросу освоения территории Среднего Подонцовья в период активизации политики российской военно-земледельческой колонизации в данном регионе. Период характеризуется переходом от полукочевого и кочевого хозяйственного быта к полной оседлости местного населения (XVI-XVII вв.). Ставится вопрос о роли юртов в этом процессе. Проведено сравнение употребления этого термина в России, в среде донского казачества и у татар. В тюркском понимании, в восприятии населения южнорусских окраин и донского казачества значение этого понятия в целом было сходно. Сделан вывод о том, что юрты как форма экономического освоения Поля предшествовали разворачиванию русской земледельческой колонизации, способствовали усилению политического влияния России, а также были одной из форм включения новых территорий в административную систему пограничных уездов России.
\end{abstract}

Ключевые слова: Поле, юрты, Среднее Подонцовье, город Царёв-Борисов, заселение, Донбасс в XVI-XVII вв.

Для цитирования: Чепига Г.Г. 2021. Северный Донбасс в экономической и политической системе Российского государства в XVI-XVII вв.: юрты, сторожи, города на Поле. Via in tempore. История. Политология, 48 (1): 132-140. DOI: 10.52575/2687-0967-2021-48-1-132-140.

\section{Northern Donbass in the economic and political system of the Russian state in the XVI-XVII centuries: yurts, watchmen, cities in the Field}

\author{
Galina G. Chepiga \\ Donetsk State Music Academy named after S.S. Prokofiev, \\ 44 Artema St., Donetsk, 83086, DPR \\ E-mail: chepiga_galina@mail.ru
}

\begin{abstract}
This article is devoted to the topic of the Middle Podontsovye territory development during the period of strengthening of the political and economic influence of Russia in this region. The period is characterized by the transition from a semi-nomadic and nomadic economic life to the complete settledness of the local population (XVI-XVII centuries). The article touches upon the question of the yurts role in this process. A comparison of using this term in Russia among the Don Cossacks and among the Tatars is made. The meaning of this concept was generally similar in the Turkic understanding and in the southern Russian outskirts and the Don Cossacks' perception. The coverage of the Donetsk region territory by the guard service of the Russian state contributed to the acceleration of the region economic development by the population of the southern Russian outskirts. Tsarev-Borisov became the first Russian city built on the territory of the Middle Podontsovye. With its construction, the entire Middle Podontsovye was included in the administrative system of Russia. After the burning of the city, the owner of the yurts was the Svyatogorsk Monastery, then the newly built Russian cities - Tor, Mayatsky, TsarevBorisov of the second settlement. Later, rural settlements appeared at the locations of the yurts and there
\end{abstract}


was a transition from the yurt way of life to the agricultural one. It is concluded that yurts, as a form of economic development of the Field, preceded Russian agricultural colonization. At the same time, yurt was an administrative unit that was intended for colonization, including unpopulated areas into the administrative system of the.

Key words: Field, yurts, Middle Podontsovye, Tsarev-Borisov town, settlement, Donbass in the XVI-XVII centuries.

For citation: Chepiga G. G. 2021. Northern Donbass in the economic and political system of the Russian state in the XVI-XVII centuries: yurts, watchmen, cities jn the Field. Via in tempore. History and political science, 48 (1): 132-140 (in Russian). DOI: 10.52575/2687-0967-2021-48-1-132-140.

\section{Введение}

Эпоха Нового времени для Российского государства обозначилась феноменом возникновения на её восточных и южных рубежах новой геополитической реальности - «Поля». Логика исторического процесса привела к тому, что Российское государство и его население вынуждены были вступить во взаимодействие с ним. Порубежье государства с наследниками степных империй не было статичной границей и отличалось активной динамикой взаимодействия. Полевые окраины России служили базой для разворачивания военно-земледельческой колонизации и распространения государственного влияния на территорию Поля. Каждый участок пограничья имел в данном контексте свою специфику.

\section{Объекты и методы исследования}

Целью данной работы является рассмотрение особенностей упомянутых общероссийских процессов для территории Среднего Подонцовья. В районе среднего течения Северского Донца расположена северная часть историко-географического региона Донбасс. Донбасс - область, которая определяет историческую территорию в зоне Северского Донца и Донецкого кряжа.

Юг Харьковской области принято относить к исторической области «Слобожанщина», несмотря на её историческое отношение к Белгородскому краю, Белгородскому полку и разряду. В районе впадения реки Оскол в Северский Донец (юг Харьковщины) начинается регион Среднего Подонцовья, тут в 1599 г. был построен первый русский город в указанном регионе, с которого начался процесс заселения современной территории Донбасса - Царёв-Борисов [Кравченко, Кузин и др., 2017; История Донбасса..., 2018].

Методологическая база исследования базируется на принципах историзма и объективности, а также на общенаучной и исторической методологии. Хронологический метод позволил показать процесс освоения территории Донбасса в динамике, сравнительный сопоставить применение понятия «юрт» в употреблении тюркских и славянских народов, системный метод позволил выдвинуть предположение о наиболее вероятной дате основания Святогорского монастыря, генетический - проследить процесс распространения российского государственного влияния на территорию Поля в районе Среднего Подонцовья и его связь с освоением приграничной территории в форме юртов.

\section{Результаты и их обсуждение}

Первый город со времён средневековья на территории Среднего Подонцовья возник только к концу XVI в., однако известия о нахождении русских сторож на территории края поступают с начала XVI в. Так, немецкий дипломат, посетивший Россию в 1517 и 1526 гг., Сигизмунд Герберштейн, оставил сразу несколько сведений о территории будущего Донбасса, относящихся к началу XVI в. Уже в то время существовало название местности - «Святые Горы», отмечен «Великий Перевоз», служивший переправой с Крымского на левый, Московский берег Донца в районе Святогорья. Также дипломат 
упомянул о том, что великий князь Московский Василий Иванович в эту местность ежегодно посылал служилых, о которых им сделана следующая запись: «...воины, которых князь каждый год посылает туда для разведывания и отражения татарских набегов...» [Герберштейн, 1866, с. 103]. В XVI в. Святые Горы неоднократно упоминаются в качестве сторожевого поста Российского государства на его южных окраинах. В Патриаршей летописи под 1555 г. имеется следующее известие: «И как воеводы пришли верх Мжа и Коломока, и прибежал к ним сторож от Святых Гор, да станишник Лаврентей Колтовской товарища прислал с тем: царь крымской Донец перелез со многыми людми, а идет к Резаньским или к Тулскым украйнам» [ПСРЛ, т. 13, 1904, с. 256]

В середине XVI в. к Донцу уже ездят путивльские станичники. В 1571 г. экспедиция Михаила Тюфякина и Матвея Ржевского установила пограничные знаки, выбитые на дубах, на конечных точках русских станичных разъездов. В Поле эти знаки доходили до р. Айдар.

Боярин М. Воротынский по «расспросу» составил роспись сторож, семь из которых располагались на Донце, три - на территории будущего Донбасса. Указывались географические ориентиры и расстояния между ними и сторожами. Для досмотра пунктов стоянки голов и сторожей была послана экспедиция. Она же устанавливала пограничные знаки [Беляев, 1848, с. 17]. Роспись Донецких сторож по дозору М. Тюфякина и М. Ржевского отличается большей точностью, чем роспись М. Воротынского «по расспросу» (например, сторожа Бахмутовская от Святогорской отстоит скорее на полтора днища, чем на полднища, днище - это день пути). Станичная служба в районе Торских озер и Среднего Подонцовья в источниках проявляется регулярно на протяжении и всего XVII в. C постройкой первых русских городов на территории Донбасса - Маяцкого (1663г.), Тора (1676 г.), Райгородка (1684 г.) - сторожевая и станичная службы стали обязанностью гарнизонов этих городов [Материалы для истории..., 1886, с. 120-122]. Данные города фиксируются как «города на Поле», г. Маяцкий входил в число городов Белгородского полка и разряда [Загоровский, 1969, с. 159].

Таким образом, по письменным источникам мы видим, что Донецкий край с XVI в. входил в политическую зону влияния Российского государства, к концу XVI в. относится первая попытка осадить постоянное население, к концу XVII в. территория степного Донбасса впервые официально вошла в состав России по Константинопольскому миру с Турцией. В соответствии с договором 1700 г. Россия не только отстояла Среднее Подонцовье, но и продвинула границу государства в степи значительно южнее реки Бахмут. Однако до установления границы на местности дело не дошло.

Тем не менее полевая окраина российского государства, порубежье, всё ещё не имея чётких границ, теперь продвинулась на юг. На юг, в «новые земли», пошли промысловики солевары и иные отходники. Но освоение края было приостановлено внешнеполитическими неудачами. Русско-турецкая война 1710-1713 гг. закончилась неудачно для России. По результатам Прутского похода Петра I был заключён Прутский мир (1711 г.), затем Адрианопольский трактат (1713 г.) В результате города Бахмут, Тор, Маяцкий остались пограничными крепостями, т. к. граница прошла недалеко от рек Северский Донец и Top. В 1714 г. было произведено разграничение территорий между Турцией и Россией их представителями на местности, в т. ч. в Подонцовье [Артамонов, 2019, с. 395]. Так впервые в истории южнорусское Пограничье в этом районе обрело чёткие контуры государственной границы.

Однако кроме усиления политического влияния Российского государства в Подонцовье следует обратить внимание на экономические особенности освоения региона.

Так, появление сторожевой службы в Подонцовье предполагало многомесячное нахождение станичников в Поле, что делало бы их задачу невыполнимой, если б не возможность их занятий промыслами. Можно предположить, что станичники не только знали промысловые угодья, но и сами их разведывали. Поскольку станицы и сторожа набира- 
лись из служилого сословия порубежных городов России, то их (и членов их семей) можно считать первыми владельцами юртов (уходов) в регионе. Сторожевая служба внесла свою долю участия в формирование юртовой экономики, характерной для полевых окраин России.

Исследователями все чаще подмечается тот факт, что «Поле» является особым геополитическим регионом. Так, в диссертационном исследовании «Южное порубежье Российского государства в конце XVI-XVII вв. (на примере Среднего Поосколья)» автором был поставлен вопрос о необходимости обобщающего термина. Приведем один из тезисов автора диссертации С.С.Кушнарева: «Формирование природно-географического региона дает возможность местному сообществу выработать топоним, относящийся ко всей его территории. В данном случае таким топонимом выступает «Поле» как название степных и лесостепных участков южнорусских территорий, не имевших постоянного населения и четких административных границ». С.С. Кушнарев поставил вопрос не только об обобщающем географическом термине, но и о специфическом хозяйственно-культурном облике Поля: «Сюда мы относим колонизацию (заселение и хозяйственное освоение территории), приспособление переселенцев к новым природно-климатическим условиям, внедрение новых типов хозяйствования, нашедших отражение в новых формах землевладения и землепользования» [Кушнарев, 2015]. К особенностям землепользования на территории Поля, безусловно, следует отнести юртовые владения.

Исторический процесс на территории Среднего Подонцовья имел два направления развития, которые в самом общем виде можно представить как историю земледельческого и скотоводческого хозяйственно-культурных типов.

Полная оседлость в данном регионе предполагала обеспечение населения продуктами земледелия собственного производства. Земледельческое освоение и заселение Среднего Подонцовья широко развернулось во второй половине XVIII в., когда сложились необходимые предпосылки политического и экономического характера. Этому способствовал рост миграционного потенциала, направленность внутренней и внешней политики Российского государства. Однако продолжительный период времени ведение собственно земледельческого хозяйства на данной территории было невозможным, как и ведение полноценного кочевнического хозяйства. Возникли переходные формы. То же можно сказать и о государственном влиянии на просторы степи-лесостепи как со стороны Крыма, так и со стороны Российского государства. Принадлежность к этим государствам территории Поля, попытки хозяйственного и административного освоения носили переходный характер, который ярче всего проявлялся в бытовании на землях Подонцовья в XVI-XVII вв. такой формы, которая получила в документах наименование «юрт».

О юртах на территории Поля упоминают источники: отписки, сказки, грамоты и пр. Самый известный документ о юртах Среднего Подонцовья - это опубликованный Д.И. Багалеем «Наказ воеводам Богд. Бельскому и Сем. Алферову о постройке города Царевоборисова», где говорилось, что после устройства города необходимо послать людей на Донец и Оскол, велеть атаманам прибыть со всех рек, записать, кто в каком юрте атаман и где есть юрты, и кто в них хозяин. Предлагалось также сообщить держателям юртов, что царь пожаловал владеть ими, а если появятся черкасы, сгонять их с рек [Материалы для истории..., 1886, с. 10]. Таким образом, наличие юртов на Среднем Донце зафиксировано уже к концу XVI в.

Слово «юрт» тюркского происхождения. Юрт - территория для кочевья, место стоянки [Сборник материалов..., 1941, с. 305]. Целесообразно сравнить содержание этого термина с бытовавшим тогда термином улус. По документам, опубликованным В.Г. Тизенгаузеном, видно, что улус - это территория, которой правит властитель, а после него - его наследники (в частности, Джучи-хан) [Там же, с. 42]. В отличие от этого юрт, исходя из контекста, написанного в документах, - территория, находящаяся во владении. К примеру, «улус, находившийся в пределах реки Ирдыш, поручил Чингис-хан управле- 
нию Джучи-хана. Юрт Джучи находился в пределах Ирдыша и столица устроена там же» [Там же, с. 64]. Т. е. улус и юрт не равнозначные понятия. Первое - политическое, второе - экономическое. Подтверждением тому неоднократное использование термина в дальнейшем повествовании: «...направился из пределов джучиевых юртов..., Джучи, перекочевывая и переходя из юрта на юрт..., юрты для летовья и зимовья разделим (между собою) по справедливости..., отправились каждый в свой юрт, ...юрт Тулуя находился в сопредельности Угетая» [Там же, с. 77, 80].

Таким образом, у монголо-татар «юрт» представлял собой хозяйственноэкономическую единицу, ограниченную территориально. Как один из видов территориального деления юрт имел и некоторое административное значение. Из контекста приведенных документов видно, что размеры юртов у монголо-татар были весьма различны. Юртом, т. е. владением, могло называться даже государственное или автономное образование, что сближало его с русским понятием «вотчина».

Близкие соседи татар в степи - донские казаки. Понятие «юрт» у них известно с XVI в. Донские казачьи юрты смыкались с воронежскими уходами. Там южнорусская окраина постепенно переходила в юртовые владения (фактически заимки) верхнедонских казаков. В истории вольного казачества слово «юрт» и хозяйственное явление, стоящее за ним, сохранилось и стало частью экономического быта донских казаков.

Можно было бы предположить, что к границам Белгородского уезда также продвигались донские юрты (вверх по Северскому Донцу) и упоминаемые в документах о строительстве Царе-Борисова казаки - представители донского казачества. Однако прямых свидетельств этому нет.

Воронежский уезд, как и другие пограничные со степью уезды России, имел в составе заселённую и гораздо большую по площади незаселённую части. Последняя делилась на станы, состояла из ухожьев на откупе, т. е. имела редкое население, ведущее полуоседлый или неоседлый образ жизни в Поле. Белгородский уезд также частично делился на станы, однако его традиционной хозяйственной единицей незаселённой части были юрты.

Юрты упоминаются в источниках совместно с ухожьем, вотчиной, станом. По контексту использования понятий «юрты» и «ухожьи» мало отличаются. Так, в 1685 г. на месте Битюцкого ухожья в Воронежском уезде существовало 12 юртов [Загоровский, 1969, c. 40]. Но если Воронежский уезд имеет незаселённую часть - ухожьи или вотчины, реже - юрты, то белгородские служилые люди владели чаще юртами. Как правило, в качестве владельцев фигурируют русские служилые люди. Юртовая часть Белгородского уезда именовалась Донецкой волостью и доходила до впадения р. Оскол в Северский Донец. Например, упоминается «Донецкая волость, район «белгородских юртов» [Загоровский, 1969, c. 46].

На южной границе Белгородских юртов был основан в 1599 г. город ЦарёвБорисов. Однако правительству к этому времени было известно о наличии уходников и ниже по течению Северского Донца. Их и было приказано взять на службу, т. е. легализовать их положение, записав как владельцев юртов.

Всё время с начала 20-х годов, когда уже имеем сведения о Святогорском монастыре, Северский Донец был весьма оживленной транспортной артерией. Ежегодно по нему проходило от 80 до 200 будар, направлявшихся из Белгорода на Дон и обратно [Куц, 2009 , с. 61]. Известно, что в 20-х годах XVII в. Святогорский монастырь пользовался землями «выше монастыря от р. Оскольского устья вниз по Донцу, пониже монастыря по казачьи юрты по Сухарев да по речку Черный Жеребец, да с другой стороны Донца по речку Бахмутову» [Святогорская Успенская..., 1880, с. 42]. Среди этих земель известны Крестовский и Репнинский юрты. Фактически Святогорский монастырь получил во владение те же угодья, которые были записаны за держателями юртов во время первого заселения Царёва-Борисова. После постройки новых городков эти территории частично перешли во 
владение их жителей [Чепига, 2012, с. 160]. Белгородским исследователем А.И. Папковым отмечено, что в конце XVI - начале XVII вв. на юге России появляется целый ряд монастырей и что почти все монастыри на осваиваемых землях открывались практически сразу после постройки нового города [Папков, 2011, с. 115]. Мы не имеем сведений о точной дате основания монастыря в Святых горах, но связь между основанием города ЦарёваБорисова и Святогорским монастырём очевидна. Если монастырь был основан, как и другие монастыри юга России, по приказу государственной и церковной властей в связи с постройкой нового города, центра колонизации, и должен был открыться почти сразу после постройки нового города, то его основание можно предполагать в 1600-1601 гг. Обострение экономической и политической обстановки в стране в последующие годы делает маловероятным издание приказа о его основании до окончания Смуты. Первое письменное упоминание о Святогорском монастыре на данный момент датируется 1620 г. [Дедов, 2014, с. 89], сожжение Царёва-Борисова большинство исследователей относят к 1612 г. [Чепига, 2012]. По данным А.А. Новосельского, «Царёв-Борисов был сожжен, повидимому, татарами в 1612 г., когда «бояре под Москвою стояли»; «обгорелый наряд был вывезен в Белгород» [Новосельский, 1948, с. 67].

Территория, где находились юрты-урочища, была после смутного времени во владении Святогорского монастыря и считалась одним гигантским владением, пока не были построены новые города - Царёв-Борисов второго заселения, Маяцкий и Тор. В 1659 году святогорские старцы жаловались в Москву: «...к Святогорскому монастырю было исстари ваше Государское жалованье на пропитание нам богомольцам вашим в верх и на низ по реке по Донцу девять юртов. Из тех юртов было в дом Пречистые Богородицы ... дохода со всякого юрта по два рубли, по два пуда меду, по кунице. И ныне те угодья отняли у нас Борисова города черкасцы и всякие жилецкие люди и торские солевары насильством без твоего Государева указа неведомо почему...» ${ }^{24}$. Юрты на данной территории упоминаются в течение всего XVII столетия, причем фигурируют как юрты донского казачества, так и белгородских людей. Встречаются данные об использовании донецких юртов черкасами. Так, в июне 1653 года были получены сведения со Святых Гор от черкашенина Ивашки Баскраева из Теплинского юрта о посольстве крымчан к гетману Богдану Хмельницкому [Акты..., 1894, с. 328-329].

Дополнительный перечень среднедонецких юртов, переданных в общее владение жителям городов в 1666 г., следующий: «р. Балаклея Малая, озеро Ильмень, затон Берецкий, колодязь Студенок, затон Пичугин, колодязь Нетригус, p. Тор, р. Бахмут, р. Чорный Жеребец, р. Красная, р. Боровая, 7 озер солёных» [Юркевич, 1932, с. 49]. Выше по течению находились юрты Савинский, Берецкий, Изюмский [Булавинское восстание..., 1935, c. 97].

Как видно из приведенного материала, постройка Царёва-Борисова стала отправным событием для включения всей территории Среднего Подонцовья в административную систему Российского государства.

Первыми поселениями, возникшими в Новое время в Среднем Подонцовье, были Царёв-Борисов и Святогорский монастырь, но постоянного населения в регионе не прослеживается до 1663 г., когда был построен г. Маяцкий. До этого на территории края отмечается существование различных промыслов, которыми занимались уходники, а также наличие военных сил Российского государства - сторож, станичников и других отрядов, посылаемых на Поле со специальными заданиями. И первые поселения, и первые города зависели от поставок из центра. Монахи и служилые люди получали пропитание и жалованье из южнорусских городов, хотя многие из них были держателями юртов. Уходники также экономически были связаны с городами южнорусской окраины [Куц, 2009, с. 90].

${ }^{24}$ Российский государственный архив древних актов (РГАДА). Ф. 210. Оп. 12. Столбец 481. Л. 295-295 об. 
Юрт выступает в качестве формы освоения приграничной территории в условиях существования Поля. Классик исторической науки в области заселения Центрального Черноземья и колонизации Поля В.П. Загоровский в одной из своих работ отметил: «Оттесняя вольных казаков к югу, приглашая их на службу в новые города, русское правительство в 90-е гг. XVI в., видимо, начало одновременно раздавать далёкие южные земли и московским землевладельцам - сначала в виде промысловых угодий, «юртов» [Загоровский, 1991, с. 235]. Материалы по заселению Донецкого региона подтвердили это предположение ученого.

\section{Заключение}

Таким образом, юрты - это форма хозяйственного освоения природного ландшафта в условиях присваивающего хозяйства. В тюркском понимании, в восприятии населения южнорусских окраин и донского казачества значение этого понятия в целом было сходно. Города, которые строились на южной окраине России: Тор (совр. г. Славянск), Маяцкий (совр. с. Маяки), Райгородок (совр. пгт Райгородок) не имели сельской округи. Однако их жители, получая жалованье за службу, одновременно имели юрты. Территории уходов, как и сами жители, были приписаны к соответствующим городам. Юрты как форма экономического освоения Поля предшествовали русской земледельческой колонизации, способствовали усилению политического влияния России, а также были одной из форм включения новых территорий в административную систему Российского государства. Это имеет прямое отношение к формированию населения современного Донбасса, первым страницам его истории Нового времени.

\section{Список источников}

1. Акты Московского государства. Т. 2. Разрядный приказ. Московский стол. 1635-1659. Спб., 1894, 773 с.

2. Булавинское восстание. 1707-1708. Труды историко-археографического института АН СССР. Т. ХІІ. М., Изд-во политкаторжан, 1935, 528 с. 229 c.

3. Герберштейн С. Записки о Московии. СПб., В типографии В. Безобразова и комп., 1866,

4. Материалы для истории колонизации и быта Степной окраины Московского государства (Харьковской и отчасти Курской и Воронежской губерний) в XVI-XVIII столетии. Т. 1. Багалей Д.И. Харьков, Тип. К.П. Счасни, 1886, 358 с.

5. Полное Собрание Русских Летописей. T. 13. 1-я половина. VIII. Летописный сборник, именуемый Патриаршею или Никоновскою летописью. Под ред. С.Ф. Платонова при участии С.А. Адрианова. СПб.. Типография И.Н. Скороходова, 1904, 302 с.

6. Сборник материалов, относящихся к истории Золотой орды. Извлечения из персидских сочинений, собранные В.Г. Тизенгаузеном. Т. 2. М., Л., Издательство академии наук СССР, 1941, $307 \mathrm{c}$.

7. Святогорская Успенская общежительная пустынь в Харьковской епархии. Харьков, Тип. Окружного штаба, 1880, 166 с.

\section{Список литературы}

1. Артамонов В.А. 2019. Турецко-русская война 1710-1713 гг. М., Издательство «Кучково поле», $448 \mathrm{c}$.

2. Беляев И.Д. 1848. О сторожевой и станичной службе на польской окраине Московского государства. М., Тип. Университета, 86 с.

3. Дедов В.Н. 2014. Святые Горы. Иллюстрированная история. Донецк, «Донбасс», ТОВ «РА «Ваш імідж», $464 \mathrm{c}$.

4. Загоровский В.П. 1669. Белгородская черта. Воронеж, Изд-во Воронежского университета, $304 \mathrm{c}$. 
5. Загоровский В.П. 1991. История вхождения Центрального Черноземья в состав Российского государства в XVI веке. Воронеж, Изд-во ВГУ, 272 с.

6. История (история Донбасса от древности до современности): учебное пособие. Под общей редакцией проф. Л.Г. Шепко, проф. В.Н. Никольского. Донецк, ДонНУ, 2018, 730 с.

7. Кравченко Э.Е., Кузин В.И., Чепига Г.Г., Ляшенко В.Г. 2017. Очерки истории Донецкого края (с древнейших времён до 1917 года). Музейный вестник Республики. Донецк, Типография «РА ДОН», 495 с.

8. Куц О.Ю. 2009. Донское казачество в период от взятия Азова до выступления С. Разина (1637-1667). СПб., «Дмитрий Буланин», 456 с.

9. Кушнарев С.С. 2015. Южное порубежье Российского государства в конце XVI-XVII вв. (на примере Среднего Поосколья): дис. ... канд. ист. наук: 07.00.02. Харьков, Электронная книга, 280 с. Режим доступа: http://history.karazin.ua/themes/history/resources/57863ab0a3983f8072f938cb40f7384f.pdf (дата обращения: 08.01.2021).

10. Новосельский А.А. 1948. Борьба Московского государства с татарами в первой половине XVII в. М.-Л., АН СССР, 447 с.

11. Папков А.И. 2011. Освоение Российским государством своих южных окраин и основание монастырей в конце XVI - начале XVII веков. НИУ БелГУ. Научные ведомости БелГУ. Сер. История. Политология. Экономика. Информатика. Вып. 18.7 (102): 110-115.

12. Чепіга Г.Г. 2012. Українська та російська історіографія про перше заселення м. Цареборисова та особливості колонізаційних процесів навколо нього. Святогірський альманах. 2012. Збірка наукових праць. Донецьк. Видавництво «Донбас», ТОВ «РА «Ваш імідж»: 157-166.

13. Юркевич В. 1932. Еміграція на схід і залюднення Слобожанщини за Б. Хмельницького. Киев, ВУАН., 191 с.

\section{References}

1. Artamonov V.A. 2019. Turecko-russkaya vojna 1710-1713 gg. [Turkish-Russian war of 1710-1713]. M., Izdatel'stvo «Kuchkovo pole», 448 p.

2. Belyaev I.D. 1848. O storozhevoj i stanichnoj sluzhbe na pol'skoj okraine Moskovskogo gosudarstva [On the guard and stanitsa service on the Polish outskirts of the Moscow state]. M., Tip. Universiteta, $86 \mathrm{p}$.

3. Dedov V.N. 2014. Svyatye Gory. Illyustrirovannaya istoriya [Holy Mountains. Illustrated history]. Doneck, «Donbass», TOV «RA «Vash imidzh», 464 p.

4. Zagorovskij V.P. 1969. Belgorodskaya cherta [Belgorod line]. Voronezh, Izd-vo Voronezhskogo universiteta, $304 \mathrm{p}$.

5. Zagorovskij V.P. 1991. Istoriya vhozhdeniya Central'nogo Chernozem'ya v sostav Rossijskogo gosudarstva v XVI veke [The history of the Central Black Earth Regionentry into the Russian state in the 16th century]. Voronezh, Izd-vo VGU, 272 p.

6. Istoriya (istoriya Donbassa ot drevnosti do sovremennosti): uchebnoe posobie [History (history of Donbass from antiquity to the present): textbook]. Pod obshchej redakciej prof. L.G. Shepko, prof. V.N. Nikol'skogo. Doneck, DonNU, 2018, 730 p. (in Russian).

7. Kravchenko E.E., Kuzin V.I., Chepiga G.G., Lyashenko V.G. 2017. Ocherki istorii Doneckogo kraya (s drevnejshih vremyon do 1917 goda) [Essays on the history of the Donetsk region (from ancient times to 1917)]. Muzejnyj vestnik Respubliki. Doneck, Tipografiya «RA DON». 495 p. (in Russian).

8. Kuc O.Y. 2009. Donskoe kazachestvo v period ot vzyatiya Azova do vystupleniya S. Razina (1637-1667) [Don Cossacks in the period from the capture of Azov to the speech of S. Razin (1637-1667)]. SPb., «Dmitrij Bulanin», 456 p.

9. Kushnarev S.S. Yuzhnoe porubezh'e Rossijskogo gosudarstva v konce XVI-XVII vv. (na primere Srednego Pooskol'ya): dis. ... kand. ist. Nauk [Southern border of the Russian state at the end of the XVI XVII centuries (on the example of the Middle East): dis. ... Cand. Hist]. Kharkiv, 2015. Elektronnaya kniga. 280 p. Rezhim dostupa: http://history.karazin.ua/themes/history/resources/57863ab0a3983f8072f938cb40f7384f.pdf (data obrashcheniya: 08.01.2021).

10. Novosel'skij A.A. 1948. Bor'ba Moskovskogo gosudarstva s tatarami v pervoj polovine XVII v. [The struggle of the Moscow state with the Tatars in the first half of the XVII century]. M.-L., AN SSSR, $447 \mathrm{p}$. 
11. Papkov A.I. 2011. Osvoenie Rossijskim gosudarstvom svoih yuzhnyh okrain i osnovanie monastyrej v konce XVI - nachale XVII vekov [The development by the Russian state of its southern outskirts and the founding of monasteries in the late 16th - early 17th centuries]. NIU BelGU. Nauchnye vedomosti BelGU. Ser. Istoriya. Politologiya. Ekonomika. Informatika. 2011. Vyp. 18.7 (102): 110-115 (in Russian).

12. Chepiga G.G. 2012. Ukraïns'ka ta rosijs'ka istoriografiya pro pershe zaselennya $\mathrm{m}$. Careborisova ta osoblivosti kolonizacijnih procesiv navkolo n'ogo [Ukrainian and Russian historiography about the first settlement of Tsareborisov and features of colonization processes around it]. Svyatogorsk miscellany. 2012. Collection of scientific works. Donetsk., Vidavnictvo «Donbas», TOV «RA «Vash imidzh»: 157-166 (in Ukrainian).

13. Yurkevich V. 1932. Emigraciya na skhid i zalyudnennya Slobozhanshchini za B. Hmel'nic'kogo [Emigration to the east and population of Slobozhanshchyna under B. Khmelnytsky]. Kiev, VUAN. 191 p. (in Ukrainian).

\section{ИНФОРМАЦИЯ ОБ АВТОРЕ}

Чепига Галина Геннадиевна, кандидат исторических наук, старший преподаватель кафедры гуманитарных дисциплин Донецкой государственной музыкальной академии имени С.С. Прокофьева, г. Донецк, ДНР

\section{INFORMATION ABOUT THE AUTHOR}

Galina. G. Chepiga, Candidate of Historical Sciences, senior lecturer of the Department of Humanities, Donetsk State Music Academy named after S.S. Prokofiev, Donetsk, DPR 